\title{
THE RELIANCE OF BUDGETS OF EU MEMBER STATES ON VAT REVENUES. IMPLICATIONS IN CRISIS AND POST-CRISIS PERIODS
}

The paper aims to provide quantitative background for policy prescriptions in the EU Member States facing a dependence on value added tax revenues. Our methods include a descriptive analysis and also an empirical study on the main determinants of value added tax revenues that resort to panel methodology. We conclude that preserving value added tax revenues as the main source for the state budget receipts is harder to achieve by tax rate reassessment, but is more easily attained by shaping the consumption path. If managing the value added tax rate is an unavoidable measure in some particular circumstances, more attention should be paid to confer that it is the right size in relation to the economic development.

Keywords: state budget, VAT, final consumption of households, panel econometrics, EU-28 JEL Classifications: H25, H30, H12

DOI: 10.15611 aoe.2019.1.07

\section{INTRODUCTION}

The supervision of government budgets has been facing real challenges in the last decade, since the huge financial and economic crisis of 2007-2010. The crisis has raised, maybe more than ever, questions related to the more efficient and rational use of public resources. Important government incomes tend to decrease noticeably under crisis conditions and to affect the proper functioning of the public system. This study ascertains the dependence of the public budget on particular receipts, which in crisis or in post-crisis periods may lead to introducing compensation measures. These measures, if not well-established, might run against the equity and efficiency principle of public economics. Basically here we refer to value added tax (VAT), a tax that has prompted numerous discussions in the last half of the 20th century and particularly during and after the economic crisis when changes to VAT became a central part of countries' policy response.

\footnotetext{
*Faculty of Economics and Business Administration, Department of Finance, "Babeş-Bolyai" University Cluj-Napoca, Romania.
} 
Having its roots in France, VAT has spread into more than 150 countries. Known as a "money machine" or "centrepiece of tax reform" or even "the best tax ever invented", VAT mainly owes its success to its potential to produce significant resources to the state budget, and its simplicity in tax administration. In general, studies have shown that governments that adopted VAT have collected more budget revenues compared to those countries that have not introduced this tax and improved the effectiveness of the tax system (Keen, 2007; Martinez-Vazquez and Bird, 2010; Keen and Lockwood, 2010; Owen et al., 2011). The hypothesis of VAT causing unwelcome growth in government size was addressed by Keen (2007) who claims that increases in VAT revenues are accompanied by lower tax revenues originating from other sources. Ebeke and Ehrhart (2011) share Keen's opinion. They also argue for VAT stable role in enhancing tax revenue in 103 developing countries as observed between 1980 and 2008. This effect is particularly important in low income countries, characterized by low exposure to external shocks.

Among government revenues, receipts from value added tax represent an important share and a stable one (in the EU it raised over EUR 1 trillion in 2015, i.e. 7 percent of the EU's GDP). Theoretically, this aspect is explained, firstly, by the fact that VAT is a consumption tax which could be almost inelastic to the changes in the economy. Consumption of different types of goods or services reacts in a different way to economic variations (for instance, the consumption of primary goods does not significantly deviate when revenues in the economy change). Final consumption is relatively more stable than exports, imports, companies' profits or any other tax base, as considered by Ebeke and Ehrhart (2011). Secondly, some theorists (see Tulai and Serbu, 2005) assert that a tax on consumption, being perceived at the time of purchase, is better accepted by the taxpayer compared with the income tax burden, for example. VAT compliance results in VAT additional legitimacy, allowing the government to create large reserves out of this source.

This particular standing of VAT in the public budget of many countries creates a reliance effect on the specific source, and that makes us acknowledge the challenges it induces, especially in times of crisis. Can public budget rely on it in times of crisis, and what are the proper means to ensure its outcome? During the recent crisis the state's role has grown as the state budget was burdened with additional public expenses destined for supporting the hardest hit industries by the recession, so that conserving or even increasing tax revenues became a priority. 
The studies focusing on the fiscal system reform under crisis situations sustain the idea that a tax increase should take place in those areas which affect economic growth the least, such as taxing consumption or real estate. The heavier burden of indirect over direct taxation encourages work and leads to income accumulation and investment development (Radu, 2012). Therefore, many EU countries proceeded to raise the VAT rate in crisis and post-crisis periods. Owen et al. (2011) anticipated that a growing part of VAT amongst tax receipts would continue even in post-crisis periods, because personal and corporate income as tax bases need more time to recover.

Despite its revenue and economic growth enhancing effect, VAT has some limits which have become of great interest for researchers and the European Commission in the last decade. Firstly, a serious weakness of VAT is its exposure to fraud, which reached alarming levels in the midst of the crises, after it had declined in the previous period (Martinez-Vazquez and Bird, 2010). Before the crises, VAT fraud had not yet represented a serious concern, the tax collection rate being similar to that of other government revenues (Keen, 2007; Keen and Smith, 2007). The EU administration estimate VAT-associated fraud in the EU at about 12 percent of the theoretical VAT receipts, declining recently (TAXUD, 2017). For a wider perspective of the forms taken by VAT fraud, see Keen and Smith (2007), Cornelisse and Hulsebos (2012), and for details of the losses caused by carousel-type fraud in the Member States, see Keen (2007), Keen and Smith (2007).

Secondly, VAT is a regressive tax, as the poor consume a higher share of their current income on VAT payments as opposed to the rich. From a new perspective, VAT payment in relation to income is considered as a misleading indicator of the progressivity of the VAT system. Connecting VAT payments with household expenditures, TAXUD (2013) found that in about half of the EU Member States, the VAT rates structure is progressive, leading to a lower tax burden for low-income households, while the remaining countries have a proportional VAT system and only exceptionally a regressive one. Regardless of such results, an important literature strand continues to deal with the regressive nature of VAT in relation to the aims of revenues' distribution.

Facing the extensive use of VAT in the national tax systems, both scientists and practitioners consider that some adjustments have to be made. To raise VAT and overall tax revenues, policy makers could proceed as follows: to extend the tax base, to reassess the VAT rates and/or to ensure 
better tax management. Since the last crisis, the European Commission has demonstrated a constant concern about making the VAT system simpler, more robust, more efficient, as well as fighting against VAT fraud, reducing the VAT gap and conceiving a single EU VAT area.

A set of VAT-related strategies have been implemented in the EU since the onset of the global crisis of 2007-2008. Strengthening the administrative cooperation between tax administrations, reducing errors and negligence in administering this tax, and envisaging new methods for collecting the tax, received particular attention (COM, 2008; Council Regulation, 2010; COM, 2011).

In order to compensate the regressive nature of the tax, the VAT system usually includes commodity-specific tax rates (exemptions or reduced rates). Reduced rates were considered for a long period of time as the most appropriate tool to support the consumption of certain goods or to redistribute income from the rich to the poor. TAXUD (2013) enforce a very heterogeneous pattern of VAT-rates' structures across the EU Member States, with some of them making little use of zero and reduced rates, while others apply up to four exemption types to a large number of commodities. Owen et al. (2011) claim that VAT rate differentiation and a narrow base taxed at standard rate created significant difficulties within the EU.

As European Commission states (COM, 2011), reduced rates stand for large subsidies in the EU, representing about 8.2 to 53.3 percent of VAT revenues of member states' governments. Despite attempts at addressing the regressive nature of VAT, it continues to produce inequities (MartinezVazquez and Bird, 2010). Reviewing the research on the merits of reduced rates, Owen et al. (2011) found that they are rarely effective in achieving distributional objectives. Consequently, VAT rates should be homogenized, the standard VAT rate reduced and exemptions excluded, assert Keen and Smith (2007). The hypothesis in which a VAT system based on a single rate performs better than a system containing multiple rates, is sustained also by early scientific research; see Bogetic and Hassan (1993) for a review. TAXUD (2013) estimated significant additional VAT revenues of up to 3.3 percent of GDP by abolishing zero and reduced rates. Such a measure would hit harder the lower-income households in expenditures in relative terms, and higher-income households in absolute terms, which points out the limits of VAT exemptions as redistribution tools.

Using reduced rates for redistribution purposes seemed to be a failure, so keeping these exceptions for equity reasons is no longer reasonable as theorists and practitioners have considered until recently. Particular 
measures were conceived in the EU to make VAT taxation more neutral by limiting special treatment for specific goods and services (such public goods as education, health or passenger transport; COM, 2011; Owen et al., 2011). In the case of intra-community transactions, homogenizing VAT rates would have eliminated additional costs resulting from very different national VAT systems in the EU, with numerous and uneven reduced rates. EU officials believed that restraining the use of reduced VAT rates would have allowed member countries to maintain the standard rate unchanged, or even to reduce it, and also to induce economic growth through the increase of intracommunity trade (COM, 2011).

The approach is changing nowadays by discussing a definitive VAT EU system that allows a more efficient approach of cross-border VAT fraud (COM, 2016; COM, 2017). As from 2018, more flexibility is encouraged to change the VAT rates the Member States apply to different products. A VAT system based on general rules is envisaged for uniform application across the EU. Three reduced rates could be employed without restrictions on choosing the goods and services to which they apply, but the standard rate must always be applied to an approved list of products. Ensuring the safety of public revenues is achievable by respecting the rule of at least $12 \%$ weighted average of all VAT rates. The so-called single EU VAT area is expected to enter into force in 2022.

Multiple VAT rates setting with a better distributional outcome is discussed in Collins (2014) and Gastaldi et al (2017). Evaluating the distributive effects of VAT changes in the 2009-2010 period in the Republic of Ireland, Collins (2014) found that the introduction of a second reduced rate of VAT had a progressive nature, while the increase in the standard VAT rate was regressive. Gastaldi et al. (2017) propose a general methodology based on a static microsimulation model, to analyse and improve the distributional profile of VAT over income. They suggest an alternative allocation of goods among existing rates and a new rate setting with the aim of improving the distributional outcome.

By applying EU recommendations or by running their own adaptive strategies in response to economic crisis, governments were searching either for widening the VAT base, or for reassessing the VAT rate in order to increase VAT revenues. Progress in the VAT administration area, reduction of VAT fraud and VAT gap, limits for VAT exemptions use, all served to enlarge the VAT base. As for VAT rate settings, the most common strategy was to increase the standard rate and to restrain or occasionally, to multiply 
special treatments. Starting from 2018, new strategies for increasing VAT revenues are envisaged based on a larger tax base subject to standard rate, a reduced one exposed to tax fraud and a minimum weighted average of VAT rates.

Summarizing, VAT focused empirical studies distinguish the tax revenue impact, VAT revenues determinants, and the distributive effects of VAT changes. Researchers show serious concern about the impact of VAT adjustments on the macroeconomic variables or revenue distribution, and discuss VAT receipts contributing factors less. Our study joins with the analytical and empirical studies from the recent period (Legeida and Sologoub, 2003; Keen, 2007; Kenn and Lockwood, 2010, Ángeles Castro and Ramírez Camarillo, 2014; Sarmento, 2016).

Sarmento's paper (2016) focuses on VAT revenues determinants in the EU-27 between 1998 and 2011. To the best of our knowledge, this is the only paper addressing the issue of VAT main determinants in the EU. The author shows that more revenues are gathered by tax rates increases, increasing tax administration efficiency, improving legal and institutional environment and a higher GDP per capita.

Our contribution consists firstly in extending the research field by also including the post-crisis period and adding Croatia to the EU sample. Secondly, we evaluate which factor (VAT tax base or VAT rate) has the greatest impact on VAT incomes, and which tax base proxy is the most appropriate to calculate. Thirdly, empirical analyses is conducted on the whole period (comprising pre-crisis, crisis and post crisis times), and separately on two sub periods as well, so as to differentiate the particular nature of the relationship between VAT revenues and its determinants in the crisis and post-crisis periods.

The paper's goal is to identify the alternative measures and mechanisms to be implemented so that VAT preserves its large share of the state budget. Specifically, we are interested in how to manage the VAT standard rate, and how the household consumption relates to VAT revenues.

The EU-28 Member States are analysed from 2000 to 2016 in this paper structured as follows: Section 2 argues for the dependence of the state budget upon VAT revenues, Section 3 explains in a descriptive manner the VAT receipts relationship with some macroeconomic variables, and VAT rates respectively; Section 4 is an empirical analysis of the determinants of VAT revenues in the EU; and Section 5 concludes and highlights a number of implications in terms of public policy. 


\section{VAT REVENUES IN EU MEMBER STATES' BUDGETS}

The EU Member States (EU28) are rather homogenous in terms of government revenues' structure. An analysis of EU national public budgets reveals that they have at least one common element, i.e. a large part of VAT revenues among total government receipts. On average, more than one quarter of total budget revenue originates from this very source, i.e. VAT. VAT preserved its share in the public budget during the analysed period; on average the VAT receipts increased and slightly expanded of the range. Therefore, VAT is a stable income source for the state budgets of the EU-28. Similarly, VAT receipts represent about 20 percent of government revenues collected in the G-20 group (IMF, 2010; Owen et al., 2011).

\section{Table 1}

VAT percentage of total revenues - minimum, maximum and average values for 2000, 2005, 2010, 2015 and 2016

\begin{tabular}{l|c|c|c|c|c}
\hline & $\mathbf{2 0 0 0}$ & $\mathbf{2 0 0 5}$ & $\mathbf{2 0 1 0}$ & $\mathbf{2 0 1 5}$ & $\mathbf{2 0 1 6}$ \\
\hline Minimum & 17.8 & 18.3 & 18.4 & 19.7 & 20.2 \\
\hline Maximum & 59.6 & 57.3 & 57.9 & 61.5 & 60.4 \\
\hline Average & 25.5 & 27.9 & 28.9 & 28.6 & 28.6 \\
\hline
\end{tabular}

Note: Data represent percentages of total receipts from taxes and social contributions (including imputed social contributions) after deduction of amounts assessed, but unlikely to be collected, in central government budget. Data for 2000 omit Croatia.

Source: authors' elaboration using Eurostat data.

The continuous increase in the EU average share of VAT revenues up to the year 2011, except for the year 2006 (see Table 2), reveals an upsurge in the dependence of the state budget upon this income source. In our understanding, VAT reliance occurs when a large share of public expenses depends on the VAT revenues to be mobilized to the government budget. A VAT share that rises even during times of crisis, suggests either a greater stability of the VAT tax base (i.e. consumption) to the economic fluctuations compared to some other more elastic tax bases (e.g. corporations' profits), or a government crisis response by increasing the VAT rates, or even both. The growing trend, maintained until 2011, was followed by a slightly decreasing trend for the 2011-2016 period. As such, the VAT share decreased on average by 0.4 percent in 2012, 0.3 percent less in 2013, and an extra 0.1 percent decrease in 2015. The variations are not extremely large from one period to another. Yet the crises caused a faster increase of VAT share from 
2008 to 2011 than in the previous period, followed by a slight decline as soon as the economy recovered and the other tax bases provided more government revenue. One may note that the share of VAT has stabilised in recent years at approximately 28.6 percent, which actually is substantially above the figures for the 2000s. Consequently, from the long-term perspective, an increasing VAT share can be observed in the EU-28.

Table 2

Evolution of VAT share in budget revenues. EU-28, 2000-2016

\begin{tabular}{l|c|c|c|c|c|c}
\hline & $\mathbf{2 0 0 0}$ & $\mathbf{2 0 0 1}$ & $\mathbf{2 0 0 2}$ & $\mathbf{2 0 0 3}$ & $\mathbf{2 0 0 4}$ & $\mathbf{2 0 0 5}$ \\
\cline { 2 - 7 } & 25.5 & 25.8 & 27.5 & 27.8 & 27.7 & 27.9 \\
\cline { 2 - 7 } $\begin{array}{l}\text { VAT revenues } \\
\text { percentage }\end{array}$ & $\mathbf{2 0 0 6}$ & $\mathbf{2 0 0 7}$ & $\mathbf{2 0 0 8}$ & $\mathbf{2 0 0 9}$ & $\mathbf{2 0 1 0}$ & $\mathbf{2 0 1 1}$ \\
\cline { 2 - 7 } of total receipts) & 27.7 & 27.7 & 27.9 & 28.0 & 28.9 & 29.4 \\
\cline { 2 - 7 } & $\mathbf{2 0 1 2}$ & $\mathbf{2 0 1 3}$ & $\mathbf{2 0 1 4}$ & $\mathbf{2 0 1 5}$ & $\mathbf{2 0 1 6}$ & \\
\cline { 2 - 6 } & 29.0 & 28.7 & 28.7 & 28.6 & 28.6 \\
\hline
\end{tabular}

Note: Data represent percentages of VAT revenues in total receipts from taxes and social contributions (including imputed social contributions) after deduction of amounts assessed, but unlikely to be collected, in central government budget. Data for 2000 and 2001 omit Croatia.

Source: authors' elaboration using Eurostat data.

The evidence becomes extremely heterogeneous when we look inside the EU. The spread between the minimum values and the maximum values is significant (see Table 1). The variation range for the VAT revenues share, verified for each Member State during 2000-2016 is reported in Table 3.

About two-thirds of the EU countries show a VAT share above the average (27-28\%). Among the countries with the greatest reliance on VAT revenues we can point to Croatia, Latvia, Bulgaria, Poland, Slovenia, Romania, Lithuania and Finland (all above 40\%). The group of countries with the lowest dependence on this source include the United Kingdom, the Czech Republic, Malta, Ireland, Luxembourg and Italy (all bellow 25\%). Even for these latter countries, the minimum value of the share of VAT receipts does not drop below $16.4 \%$, which still represents a significant contribution to the state budget. The countries for which the share of VAT revenues in the total budget receipts varied over a very wide range (i.e. more than a $10 \%$ deviation between the minimum and maximum values) are, in general, countries with a significant reliance on VAT revenues: Lithuania, Finland, and Romania. A general pattern shown here is: the less developed 
Table 3

Minimum and maximum values for the share of VAT revenues in total receipts, 2000-2016

\begin{tabular}{l|r|r|r|r|l|l|r|r|r}
\hline Country & MIN & MAX & SPREAD & Average & Country & MIN & MAX & SPREAD & Average \\
\hline Croatia & 55.6 & 63.1 & 7.5 & 58.5 & Sweden & 27.0 & 33.9 & 6.9 & 31.6 \\
\hline Latvia & 42.3 & 50.9 & 8.6 & 47.3 & Netherlands & 29.8 & 32.9 & 3.1 & 31.3 \\
\hline Bulgaria & 42.7 & 49.3 & 6.6 & 46.2 & Germany & 28.1 & 32.9 & 4.8 & 30.7 \\
\hline Poland & 38.7 & 44.6 & 5.9 & 42.2 & Portugal & 27.3 & 32.1 & 4.8 & 29.4 \\
\hline Slovenia & 39.6 & 45.8 & 6.2 & 42.2 & Greece & 25.7 & 32.6 & 6.9 & 29.3 \\
\hline Romania & 35.4 & 47.7 & 12.3 & 41.9 & Denmark & 25.6 & 30.9 & 5.3 & 28.9 \\
\hline Lithuania & 32.8 & 49.4 & 16.6 & 41.2 & Belgium & 24.6 & 29.5 & 4.9 & 26.7 \\
\hline Finland & 32.9 & 44.8 & 11.9 & 40.4 & Austria & 25.2 & 27.7 & 2.5 & 26.7 \\
\hline Slovakia & 36.5 & 43.1 & 6.6 & 39.9 & Italy & 22.9 & 25.9 & 3.0 & 24.6 \\
\hline Hungary & 31.2 & 40.8 & 9.6 & 37.3 & Luxembourg & 19.8 & 27.6 & 7.8 & 23.7 \\
\hline France & 36.1 & 39.9 & 3.8 & 37.2 & Ireland & 19.7 & 24.1 & 4.4 & 22.2 \\
\hline Spain & 29.9 & 39.5 & 9.6 & 34.5 & Malta & 19.7 & 23.6 & 3.9 & 21.9 \\
\hline Cyprus & 24.2 & 37.5 & 13.3 & 33.2 & Czech & 17.5 & 24.8 & 7.3 & 20.3 \\
\hline Estonia & 30.1 & 34.9 & 4.8 & 32.1 & United & 16.4 & 21.1 & 4.7 & 19.1 \\
\hline
\end{tabular}

Note: Data represent percentages in the total receipts from taxes and social contributions (including imputed social contributions) after deduction of amounts assessed, but unlikely to be collected, in central government budget.

Source: authors' elaboration using Eurostat data.

EU countries are the most VAT dependent, while the most developed are the least VAT dependent. However, Finland, France and the Czech Republic deviate from this general arrangement. For some EU countries, VAT reliance is constantly rising whilst for other countries it is related to events like economic crises. Cyprus presents a particular case since it shows one of the biggest variations of VAT share (from $24.2 \%$ in 2000 to $37.5 \%$ in 2016 , encompassing three cycles during this period).

We are wondering whether the noted dependence of state budgets on the VAT revenues is good or bad, and whether it represents an advantage or a limit for the governments in question.

\section{VAT RECEIPTS MODELLED BY CONSUMPTION AND VAT RATE - DESCRIPTIVE ANALYSES}

Section 3a describes the variations in VAT revenues while the European economy fluctuates. Section $3 \mathrm{~b}$ reviews the VAT rate measures pursued in the EU-28, related to the final consumption and VAT receipts paths. 


\subsection{VAT revenues shaped by economic trends}

Public resources are highly exposed in times of crisis, when their sources (i.e. incomes, consumption and capital) are strongly affected. Ups and downs of the economy have immediate consequences on the state budget, as fewer taxes are collected and more public resources are spent on financing the distressed areas. We investigate the relationship between macroeconomic variables and VAT revenues, firstly in a descriptive manner, and secondly through an empirical study.

The trend of continuous GDP nominal growth in the EU-28 was broken in 2008 when the economic crisis arose. A significant decline was recorded in 2009 , followed by a partial recovery in 2010 and a constant growth from then on. The VAT revenues seem to follow the same trend, except for 2008 when a slight increase of the GDP was accompanied by a decrease in VAT revenues (see Figure 1). Since VAT is a tax set upon consumption, we consider it just as relevant to relate VAT with the final consumption of households (FCH) as well.

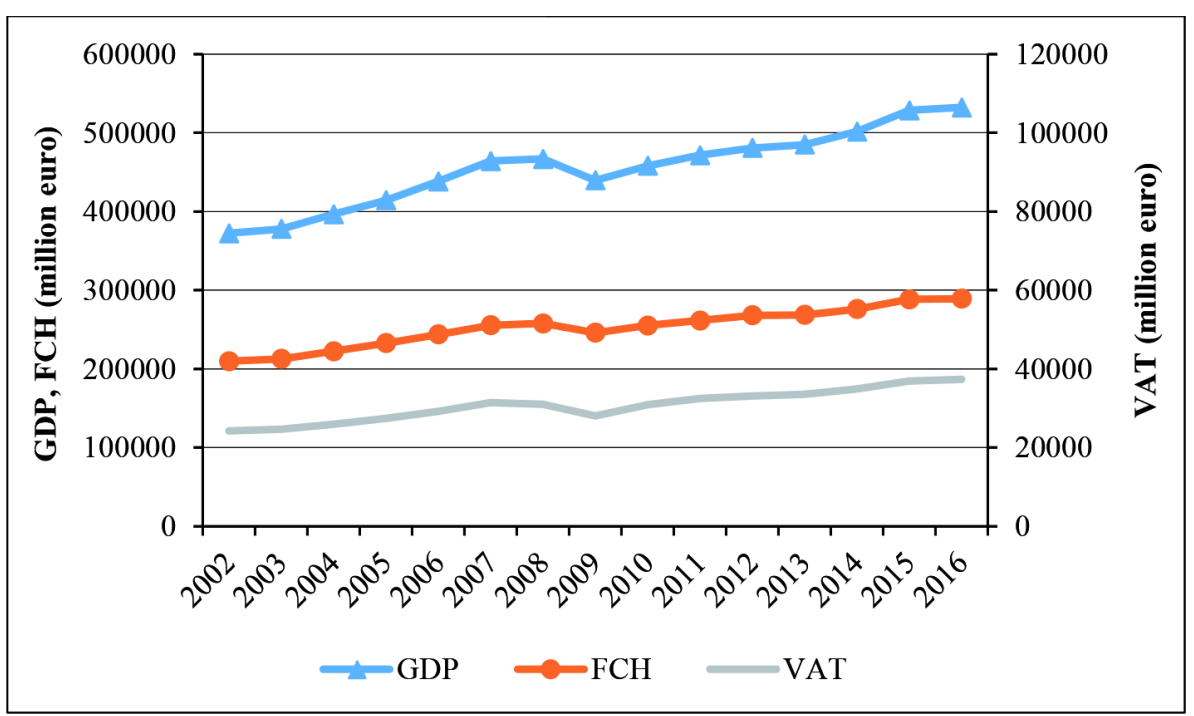

Fig. 1. The evolution of VAT, GDP and FCH for the EU28 in 2000-2016

Source: authors' elaboration using Eurostat data.

During the 2000-2007 period, VAT receipts in the EU-28 registered an average constant nominal increase, as well as in the final consumption. In 2008 and 2009 the effects of the financial and economic crisis propagated in 
such a way that VAT revenues diminished by $1.36 \%$ in 2008 compared to 2007, while FCH recorded a nominal increase of only $0.93 \%$. The widespread decline was amplified in 2009, as the decrease in VAT revenues was at about $9.29 \%$ and the nominal fall of $\mathrm{FCH}$ was approximately $4.63 \%$. In 2010, due to the economic recovery, FCH showed a nominal rise of $3.73 \%$. Moreover, VAT receipts conveyed a significant nominal increase in 2010 compared to 2009 of about $10.1 \%$, almost reaching the 2008 threshold (see Figure 1).

One observation here is that GDP, FCH and VAT revenues co-evolve with the only exception being the year 2008. Variations are deeper for VAT revenue than for GDP and $\mathrm{FCH}$, both in the recession and in the recovery times. VAT receipts are sensitive and over-responsive to transformations in the economy.

Secondly, during the 2008-2010 economic cycle, nominal VAT receipts inversely evolved compared to their share within central government revenues, as seen in Table 2. The explanation is that other government receipts impact on VAT's share as well.

The specifics of each Member State during the crisis years are further illustrated by computing the relative growth indexes, see Table 4. Out of the EU-28 countries, 18 have evolved in line with the general trend - a decreasing trend in 2009 and an increasing one in 2010 - both as regards VAT revenues and final consumption. In 14 cases out of 18, the variations are bigger for VAT revenues than for final consumption. The remaining countries are characterized by certain features that deviate from the general trend. Germany, Luxembourg and Austria did not record VAT receipts falls in that period, but on the contrary, some small rises. On the other hand, in Ireland and Slovakia the recovery period for VAT receipts was longer but different factors explained it: in Ireland, the continuous falls in final consumption seriously impacted VAT revenues, while in Slovakia the intermediate consumption decline might have reduced VAT revenues.

An overall positive evolution of VAT revenues seems to have a similar profile to the GDP trend. VAT receipts rose faster than FCH. This evidence reveals a potentially higher impact of FCH on VAT revenues than that of GDP.

The post-crisis period is characterized by the general increasing pattern of both FCH and VAT. Exceptions were recorded by Greece which encountered a serious decline of both FCH $(23 \%)$ and VAT $(10 \%)$ in the 2010-2016 period, and by Croatia who showed a small FCH decrease but a VAT increase. In 22 cases (except for Belgium, Poland, and Romania), 
growth rates were higher for VAT receipts than for $\mathrm{FCH}$, confirming the general finding of VAT over-responsiveness.

The growth rate of VAT, GDP and FCH that diminished by approximately 9 p.p. for all three variables actually makes the difference between the pre-crisis and post-crisis periods. This may be a self-adjusting effect that the crises had upon the overheated economy and the state budget.

Table 4

Relative growth indexes of final consumption and VAT revenues during the crisis and post-crisis periods

\begin{tabular}{l|c|c|c|c|c|c}
\hline \multirow{2}{*}{ Country } & FCH & FCH & FCH & VAT & VAT & VAT \\
\cline { 2 - 7 } & $\mathbf{2 0 0 9 / 2 0 0 8}$ & $\mathbf{2 0 1 0 / 2 0 0 9}$ & $\mathbf{2 0 1 6 / 2 0 1 0}$ & $\mathbf{2 0 0 9 / 2 0 0 8}$ & $\mathbf{2 0 1 0 / 2 0 0 9}$ & $\mathbf{2 0 1 6 / 2 0 1 0}$ \\
\hline Belgium & -0.46 & 4.50 & 14.27 & -2.17 & 7.15 & 13.60 \\
\hline Bulgaria & -3.81 & 3.70 & 19.62 & -18.28 & 4.53 & 33.89 \\
\hline Czech Republic & -5.44 & 6.17 & 8.25 & -6.26 & 6.50 & 25.64 \\
\hline Denmark & -2.31 & 3.25 & 13.98 & -3.52 & 2.40 & 15.10 \\
\hline Germany & -0.36 & 2.31 & 15.08 & 1.04 & 1.41 & 21.40 \\
\hline Estonia & -15.83 & 1.83 & 44.01 & -4.95 & 2.71 & 57.04 \\
\hline Ireland & -11.38 & -1.81 & 13.84 & -21.09 & -2.49 & 27.41 \\
\hline Greece & -1.08 & -3.40 & -23.16 & -12.36 & 7.25 & -10.18 \\
\hline Spain & -4.50 & 2.18 & 4.07 & -24.66 & 39.91 & 23.39 \\
\hline France & -1.42 & 2.94 & 9.58 & -5.40 & 4.05 & 13.74 \\
\hline Croatia & -6.02 & 0.78 & -0.05 & -10.97 & 2.17 & 16.56 \\
\hline Italy & -1.99 & 2.66 & 4.40 & -7.69 & 12.76 & 5.69 \\
\hline Cyprus & -6.28 & 5.39 & 0.11 & -14.90 & 3.35 & 4.14 \\
\hline Latvia & -19.69 & -0.04 & 34.83 & -27.89 & 7.48 & 70.44 \\
\hline Lithuania & -13.70 & -2.18 & 38.53 & -24.38 & 11.20 & 38.79 \\
\hline Luxembourg & 0.53 & 2.07 & 23.20 & 3.65 & 5.92 & 31.54 \\
\hline Hungary & -12.93 & 2.66 & 8.42 & -4.91 & 7.95 & 25.41 \\
\hline Malta & 3.97 & 1.83 & 25.78 & -0.35 & 4.44 & 52.69 \\
\hline Netherlands & -3.16 & 1.05 & 9.92 & -7.25 & 6.41 & 13.84 \\
\hline Austria & 1.01 & 2.77 & 17.07 & 1.01 & 2.61 & 20.27 \\
\hline Poland & -13.79 & 13.91 & 12.31 & -20.69 & 19.38 & 9.32 \\
\hline Portugal & -4.30 & 4.36 & 2.17 & -17.00 & 13.00 & 16.58 \\
\hline Romania & -18.69 & 9.00 & 31.05 & -28.85 & 20.91 & 15.53 \\
\hline Slovenia & 1.78 & 2.56 & 6.36 & -9.99 & 2.64 & 13.28 \\
\hline Slovakia & 3.23 & 1.44 & 13.22 & -5.21 & -0.93 & 29.59 \\
\hline Finland & -1.29 & 4.52 & 20.10 & -3.08 & 2.35 & 26.79 \\
\hline Sweden & -7.08 & 17.55 & 20.18 & -8.86 & 19.95 & 26.44 \\
\hline United Kingdom & -12.94 & 6.43 & 31.12 & -22.41 & 24.67 & 45.96 \\
\hline & & & & & & \\
\hline
\end{tabular}

Source: authors' elaboration using Eurostat data. 


\subsection{Implications of reassessing the VAT rate}

As the tax base of VAT (i.e. the final consumption) seriously declined during crises, VAT revenues were also exposed to the risk of dramatic falls, affecting the equilibrium of the state budget. In order to finance the subsequent additional public expenditures, some measures of VAT rates' rises were taken in the EU-28 countries.

The evidence regarding the changes in standard VAT rates in the EU Member States (see Table 5) allows to classify the states in three groups: (i) the group of states that maintain the VAT rate unchanged for a long period of time (e.g. Belgium, Bulgaria, Denmark, Austria, Sweden); (ii) the group of states that frequently amend the VAT rate (e.g. Czech Republic, Greece, Ireland, Cyprus, Hungary, Portugal, Slovakia); (iii) the group of states that adjust the VAT rate only in times of crisis (e.g. Germany, Estonia, Spain, Latvia, Lithuania, Romania, Finland, the United Kingdom). Out of 59 cases of reassessing the VAT rates, only twelve of them represent reductions, the rest standing for increasing measures of the tax rate, of which more than half occurred after 2010.

One might think that an increase in VAT rates would cause higher prices and further result in a decreased consumption, and therefore it would also reduce budget revenues. For instance, Slobodnitsky and Drucker (2008) found a strong transmission mechanism of VAT rate increases to consumer prices in Israel. A vicious circle occurs if the increase of VAT rates is not large enough to compensate for the decline in consumption. The hypothesis under which this mechanism operates is that consumption is elastic to VAT rate variations. When consumption is relatively inelastic to changes in the tax rate, and that occurs especially when we deal with primary goods, it is most likely that the boomerang effect will not take place.

During the crisis, a common practice in the EU-28 was to raise VAT rates, these situations occurring either in periods of declining consumption (2009), or when consumption was increasing (2010). The reassessments were looking to offset the tax base losses (i.e. consumption or other tax bases). The upsurge in the VAT rates went up by 5 p.p. (the maximum rise was recorded in Hungary and Romania). VAT rate revisions during the crisis have adjusted, to some extent, the trends of consumption and VAT revenues.

As shown in Table 5, the increase of VAT rates in the crisis was generally accompanied by a net decrease of consumption in the year $\mathrm{T}$ when the fiscal measure was taken and/or in the year $\mathrm{T}+1$ that followed (by at 
most $19 \%$, in Latvia in 2009). The growth rate of consumption generally ameliorates over time, except for Greece and cases when FCH increases in year $(\mathrm{T})$ and decreases in year $(\mathrm{T}+1)$ (for example Ireland in 2008 and Portugal in 2010). In most cases of decreasing consumption, VAT revenues diminished precisely in the year when the VAT rate rose (by at most $27 \%$ in Latvia in 2009), and increased after that without totally counteracting the previous decline (except for Hungary in 2009).

In the crisis, there were also situations where the rise of the VAT rate occurred while FCH was following an upward but slower path in year $(\mathrm{T}+1)$ and that reduced the VAT receipts growth rates too (as in Spain in 2010, Romania in 2010, and the UK in 2010). The perfect scenarios occurred in Germany in 2007 and Finland in 2010 where both the VAT rate and the base rate increased, positively influencing VAT receipts.

The discretionary measure of increasing the VAT rate continued in the post-crisis period in 15 countries out of the 28: the Czech Republic, Ireland, Spain, Croatia, Italia, Cyprus, Latvia, Luxembourg, Hungary, Poland, Portugal, Slovenia, Slovakia, Finland, and the UK. If prior to the financial crisis, the normal rate had increased by an average of 0.4 pp., after 2008 it rose by $2.2 \mathrm{pp}$. In only seven cases of the VAT rate increase (out of 20), the measure was generally accompanied by the rising FCH and VAT receipts, but at a slower pace especially for VAT revenues which in particular cases even decreased (i.e. Poland in 2011). For the remaining situations, such a measure occurred in the context of $\mathrm{FCH}$ declines, generally resulting in higher VAT receipts in the year when the measure was taken or in the following year (e.g. Spain 2012, Croatia 2012), or sometimes occasioning a slight decrease of VAT revenues in $(\mathrm{T}+1)$ following the $(\mathrm{T})$ year rise (e.g. the Czech Republic in 2013, Portugal in 2011). In three cases (Hungary in 2012, Cyprus in 2012, and Italy in 2011), FCH decreases in year $(\mathrm{T}+1)$ after a (T) year increase, and VAT revenues follow the same path (increase in $\mathrm{T}$ and decline in $\mathrm{T}+1$ ).

The decreases in VAT rates generally influence in a positive manner the changes in consumption and VAT revenues, which are growing. However, the growth rate of VAT receipts generally diminish in the year that follows the reduction of the tax rate; moreover, the growth rate of consumption either increases or decreases slightly. Under crisis conditions, it seems that the VAT rate reducing measures did not come up with the expected results, lessening both consumption and VAT revenues (e.g. Ireland in 2010, Great Britain in 2008, Hungary in 2006, and Portugal in 2008). 
Table 5

Relative changes in consumption and VAT receipts associated with changes in the VAT rate

\begin{tabular}{|c|c|c|c|c|c|c|}
\hline Country & TIME (T) & $\begin{array}{l}\text { CHANGE } \\
\text { IN RATE }\end{array}$ & $\begin{array}{c}\text { CHANGE } \\
\text { OF FCH(T) }\end{array}$ & $\begin{array}{c}\text { CHANGE } \\
\text { OF } \\
\text { FCH(T+1) }\end{array}$ & $\begin{array}{l}\text { CHANGE } \\
\text { OF VAT(T) }\end{array}$ & $\begin{array}{c}\text { CHANGE } \\
\text { OF } \\
\operatorname{VAT}(\mathbf{T}+\mathbf{1})\end{array}$ \\
\hline 1 & 2 & 3 & 4 & 5 & 6 & 7 \\
\hline \multirow[t]{3}{*}{$\begin{array}{l}\text { Czech } \\
\text { Republic }\end{array}$} & 01.05 .2004 & -3 & 6.42 & 11.63 & 24.40 & 12.58 \\
\hline & 01.01 .2010 & 1 & 6.17 & 4.93 & 6.50 & 7.93 \\
\hline & 01.01.2013 & 1 & -1.91 & -3.40 & 2.79 & -0.79 \\
\hline Germany & 01.01 .2007 & 3 & 1.63 & 2.31 & 15.58 & 3.41 \\
\hline Estonia & 01.07 .2009 & 2 & -15.83 & 1.83 & -4.95 & 2.71 \\
\hline \multirow[t]{5}{*}{ Ireland } & 01.01 .2001 & -1 & 9.23 & 8.87 & 4.62 & 14.23 \\
\hline & 01.03 .2002 & 1 & 8.87 & 6.80 & 14.23 & 7.38 \\
\hline & 01.12 .2008 & 0.5 & 1.74 & -11.38 & -8.85 & -21.09 \\
\hline & 01.01 .2010 & -0.5 & -1.81 & -0.67 & -2.49 & -3.10 \\
\hline & 01.01 .2012 & 2 & 0.39 & 1.57 & 4.76 & 1.50 \\
\hline \multirow[t]{4}{*}{ Greece } & 01.04 .2005 & 1 & 6.50 & 5.79 & 6.52 & 10.13 \\
\hline & \begin{tabular}{|l|l|}
15.03 .2010 \\
\end{tabular} & 2 & -3.40 & -8.01 & 7.25 & -5.87 \\
\hline & \begin{tabular}{|l|l}
01.07 .2010 \\
\end{tabular} & 2 & -3.40 & -8.01 & 7.25 & -5.87 \\
\hline & 01.06 .2016 & 1 & -1.01 & n.a. & 11.24 & n.a. \\
\hline \multirow[t]{2}{*}{ Spain } & 01.07 .2010 & 2 & 2.18 & 0.03 & 39.91 & -2.95 \\
\hline & 01.09 .2012 & 3 & -1.25 & -2.14 & 1.50 & 7.77 \\
\hline \multirow[t]{2}{*}{ France } & 01.04 .2000 & -1 & n.a. & 4.46 & n.a. & 1.32 \\
\hline & 01.01 .2014 & 0.4 & 0.82 & 1.67 & 2.74 & 2.13 \\
\hline \multirow[t]{2}{*}{ Croatia } & \begin{tabular}{|l|l}
01.08 .2009 \\
\end{tabular} & 1 & -6.02 & 0.78 & -10.97 & 2.17 \\
\hline & 01.03 .2012 & 2 & -0.95 & -0.75 & 6.52 & 1.96 \\
\hline \multirow[t]{2}{*}{ Italy } & \begin{tabular}{|l|}
17.09 .2011 \\
\end{tabular} & 1 & 2.91 & -1.33 & 1.09 & -2.51 \\
\hline & 01.10 .2013 & 1 & -1.33 & 0.49 & -2.34 & 3.35 \\
\hline \multirow[t]{6}{*}{ Cyprus } & 01.07 .2000 & 2 & n.a & 6.87 & n.a. & 13.51 \\
\hline & 01.07 .2002 & 3 & 4.43 & 5.24 & 19.43 & 24.25 \\
\hline & 01.01 .2003 & 2 & 5.24 & 9.44 & 24.25 & 15.25 \\
\hline & \begin{tabular}{|l|l|}
01.03 .2012 \\
\end{tabular} & 2 & 0.97 & -6.04 & 3.99 & -11.06 \\
\hline & 14.01 .2013 & 1 & -6.04 & 0.26 & -11.06 & 7.77 \\
\hline & 13.01 .2014 & 1 & 0.26 & 0.67 & 7.77 & 0.31 \\
\hline \multirow[t]{3}{*}{ Latvia } & 01.01 .2009 & 3 & -19.69 & -0.04 & -27.89 & 7.48 \\
\hline & 01.01 .2011 & 1 & 9.58 & 7.72 & 14.70 & 15.73 \\
\hline & 01.07 .2012 & -1 & 7.72 & 4.84 & 15.73 & 7.00 \\
\hline \multirow[t]{2}{*}{ Lithuania } & \begin{tabular}{|l|}
01.01 .2009 \\
\end{tabular} & 1 & -13.70 & -2.18 & -24.38 & 11.20 \\
\hline & 01.09 .2009 & 2 & -13.70 & -2.18 & -24.38 & 11.20 \\
\hline Luxembourg & 01.01 .2015 & 2 & 3.37 & 2.30 & -8.33 & 0.21 \\
\hline \multirow[t]{3}{*}{ Hungary } & 01.01 .2006 & -5 & -1.45 & 13.35 & -8.98 & 17.57 \\
\hline & 01.07 .2009 & 5 & -12.93 & 2.66 & -4.91 & 7.95 \\
\hline & 01.01.2012 & 2 & 0.12 & -0.73 & 6.66 & -0.12 \\
\hline
\end{tabular}


Table 5, cont.

\begin{tabular}{|c|c|c|c|c|c|c|}
\hline 1 & 2 & 3 & 4 & 5 & 6 & 7 \\
\hline Malta & 01.01.2004 & 3 & 4.67 & 5.42 & 14.92 & 18.97 \\
\hline \multirow[t]{2}{*}{ Netherlands } & 01.01 .2001 & 1.5 & 5.63 & 4.27 & 12.69 & 3.03 \\
\hline & 01.10 .2012 & 2 & 0.29 & 1.34 & 0.21 & 1.74 \\
\hline Poland & 01.01 .2011 & 1 & 5.06 & 2.56 & 8.37 & -6.66 \\
\hline \multirow[t]{5}{*}{ Portugal } & 05.06.2002 & 2 & 4.80 & 3.34 & 6.45 & 3.82 \\
\hline & 01.07.2005 & 2 & 5.53 & 5.12 & 12.38 & 5.87 \\
\hline & 01.07 .2008 & -1 & 4.17 & -4.30 & 0.63 & -17.00 \\
\hline & 01.07.2010 & 1 & 4.36 & -2.13 & 13.00 & 5.45 \\
\hline & 01.01.2011 & 2 & -2.13 & -3.90 & 5.45 & -1.89 \\
\hline \multirow[t]{3}{*}{ Romania } & 01.07 .2010 & 5 & 9.00 & 4.23 & 20.91 & 20.20 \\
\hline & 01.01 .2016 & -4 & 5.86 & n.a & -15.23 & n.a \\
\hline & 01.01 .2017 & -1 & n.a & n.a & n.a & n.a \\
\hline \multirow[t]{2}{*}{ Slovenia } & 01.01 .2002 & 1 & 6.32 & 5.17 & 11.27 & 4.38 \\
\hline & 01.07.2013 & 2 & -2.07 & 1.80 & 5.46 & 3.59 \\
\hline \multirow[t]{3}{*}{ Slovakia } & \begin{tabular}{|l}
01.01 .2003 \\
\end{tabular} & -3 & 12.83 & 16.34 & 20.82 & 19.93 \\
\hline & 01.01 .2004 & -1 & 16.34 & 12.78 & 19.93 & 14.71 \\
\hline & 01.01 .2011 & 1 & 3.31 & 3.03 & 12.64 & -8.13 \\
\hline \multirow[t]{2}{*}{ Finland } & 01.07 .2010 & 1 & 4.52 & 6.35 & 2.35 & 11.47 \\
\hline & 01.01 .2013 & 1 & 2.08 & 2.05 & 5.01 & 0.32 \\
\hline \multirow[t]{3}{*}{$\begin{array}{l}\text { United } \\
\text { Kingdom } \\
\end{array}$} & 01.12 .2008 & -2.5 & -11.22 & -12.94 & -14.08 & -22.41 \\
\hline & 01.01 .2010 & 2.5 & 6.43 & 1.73 & 24.67 & 14.90 \\
\hline & 04.01.2011 & 2.5 & 1.73 & 11.28 & 14.90 & 9.36 \\
\hline
\end{tabular}

Note: TIME (T) - the date the tax rate was modified; CHANGE IN RATE - percentage points; CHANGE OF FCH $(\mathrm{T}) /(\mathrm{T}+1)$ - relative change of $\mathrm{FCH}$ in the very year the tax rate was modified $(\mathrm{T})$ vs. the year following the one the tax rate was modified $(\mathrm{T}+1)$; CHANGE OF VAT $(\mathrm{T}) /(\mathrm{T}+1)$ - the change of VAT in the very year the tax rate was modified $(\mathrm{T}) \mathrm{vs}$. the year following the one the tax rate was modified $(\mathrm{T}+1)$. Changes are determined relative to the previous year.

Source: authors' elaboration using Eurostat data.

These results forecast a stronger connection of VAT receipts with the FCH path than with VAT rate changes. In the short run, it seems that VAT rate increasing measures were more effective in collecting public resources in the post-crisis period than in the crisis although in the long run, VAT receipts could be touched by measures increasing VAT rates.

Summing up, the relationship between the VAT rate and VAT revenues is quite strong, although the effect may be slightly delayed or it may not be lasting for too long.

We further proceed to an empirical analysis on the VAT base, VAT rate and VAT receipts interactions in order to determine the factor that best explains VAT revenues in the EU-28 countries. 


\section{EMPIRICAL ANALYSIS ON VAT REVENUES DETERMINANTS IN THE EU-28}

The research by Bogetic and Hassan (1993), Jenkins and Kuo (1995), Olexa (1999), Legeida and Sologoub (2003), Slobodnitsky and Drucker (2008), and Jenkins et al. (2000), inspired our empirical study of where VAT revenues are modelled. These papers either analyse the case of a single country over some years (i.e. employing monthly or quarterly data), or study a large sample of countries over a single year. None of these studies combine the temporal dimension with the cross-sectional one. More recent papers like Keen and Lockwood (2010), Ángeles Castro and Ramírez Camarillo (2014) and Sarmento (2016), eliminate this shortcoming of previous studies, making use of the panel technique by analysing data simultaneously in the two dimensions. Our study joins this research, by using the panel methodology.

Legeida and Sologoub (2003) review and improve the few existing methodologies in the literature that allow to estimate VAT revenues. The more usual approaches, at that time, were based on effective rates, elasticity, econometric models, trends and autocorrelation. The methodologies include ordinary least squares and ARIMA models. Keen and Lockwood (2010) apply fixed effects methodology in a panel of 143 countries over 25 years, modelling revenue ratio as dependent of VAT adoption and a set of economic variables. Ángeles Castro and Ramírez Camarillo (2014) use static and dynamic panel data techniques for analysing the impact of economic, structural, institutional and social factors on the tax revenues of 34 OECD countries over the 2001-2011 period. This paper validates the positive impact held by GDP per capita, the industrial sector and the civil liberties on tax revenue and the negative impact held by the agricultural sector and the share of foreign direct investments in the gross fixed capital formation on tax revenue. Another paper (Sarmento, 2016), assess the impact held by the tax administration's efficiency and experience, VAT rates, economic variables (i.e. imports, services and fiscal deficits) and participation in the Eurozone, on VAT revenues. They found that EU governments have been using tax rates' increases to collect more resources and higher revenues are related to better legal and institutional arrangements.

Our empirical study tests the significance of basic factors that directly impact VAT revenues (i.e. tax base and tax rate), employing the panel data methodology.

The following theoretical hypotheses are verified by our empirical analysis. 


\section{H1: The wider the base, the bigger the VAT revenues}

Generally, when production and consumption increase, we expect to collect more taxes on value added. So, we expect the empirical analysis to confirm $\mathrm{H} 1$.

H2: VAT revenues rise with the tax rate.

Increasing the VAT rate would generally result in more VAT revenues. We expect the empirical tests to find a positive influence of the standard VAT rate upon the revenues of this tax. A higher tax is associated with higher revenues, despite the negative impact that it can have on private consumption.

Eurostat data for the $28 \mathrm{EU}$ member states and the 2000-2016 period have been used. The potential tax base consists of various variables whose annual values are expressed in millions of euros while the VAT standard rate is expressed as percentages. The estimates were carried out using the panel techniques. The panel is preferred compared to the "cross-country race" analysis when dealing with a relative small sample, as we exploit the temporal dimension of the data too. The estimation method is the pooled ordinary least squares and individual effects for panel data.

Firstly, our study focuses upon the correlation between the VAT revenues and the potential tax base proxied by a set of macroeconomic variables.

The VAT base is conceived in agreement with the IMF approach and recommendations of Jenkins et al. (2000). For the first regression (1), we consider the gross domestic product (GDP) as an exogenous variable. GDP is the final value of goods and services produced in a country during a year. We add a dummy variable for 2009 in the regression in order to reveal the potential effects of the latest economic crisis.

The estimation's results are presented in Table 6. The exogenous variable's coefficient is significant with a $1 \%$ risk threshold confirming the tight relation between the exogenous and endogenous variables. The one unit increase of the gross domestic product determines an average increase of 0.06484 unit for the value added tax revenues in the EU Member States. This effect would occur if there are not any tax exemptions and VAT compliance is perfect. Sarmento (2016) also validated the positive impact held by the gross domestic product per capita on tax revenues.

GDP is not the best approximation for the value added tax base, because, on one hand, it does not include the imports (that represent part of the effective tax base), and on the other hand, it does include exports (that actually do not account for an effective tax base). Thus for the next regression (2), we use the adjusted GDP (AGDP) as an explanatory variable, 
obtained by adding the imports to the gross domestic product and by subtracting the exports (AGDP = GDP + I-E), as well as in Olexa's model and Legeida and Sologoub's model. As Olexa (1999) argues, merging exogenous variables (GDP, I, E) eliminates the estimation problems engendered by the multi-collinearity of those variables taken separately. As expected, there is a tight and direct connection between the adjusted gross domestic product and the value added taxes receipts. The result does not change significantly compared with the result obtained in the first regression.

A disadvantage of using the gross domestic product as an explanatory variable is the fact that it is expressed in market prices. Under these circumstances, we may consider the gross value added, expressed in basic prices (GVA). The third model estimates the VAT revenues as a function of the GVA and one dummy variable for the year 2009 (3). The GVA has, to some extent, a greater impact on the VAT revenues than the GDP. We further regress VAT revenues on the adjusted GVA (AGVA), obtained by adding the imports to the gross value added and by subtracting the exports $(\mathrm{GVAA}=\mathrm{GVA}+\mathrm{I}-\mathrm{E})$ (4). We find a strong relationship between the value added tax revenues and the adjusted gross value added.

GVA as a VAT base proxy could also be subjected to criticism. The gross value added shortcoming is that it omits customs duties and excise taxes, which typically account for an effective value-added tax base. On the other hand, the gross value added created in particular economic sectors (e.g. financial services, insurance, healthcare services, education) does not form a value-added tax base. Moreover, the gross domestic product and the value added are characterized by one common limitation: they include the gross fixed capital formation of enterprises that does not constitute an effective value-added tax base.

In all fiscal systems, VAT is perceived as a consumption tax. To capture the consumption effect on VAT revenues, a new linear model is considered where the final consumption expenditure of households $(\mathrm{FCH})$ is the exogenous variable. We also consider one dummy variable for the year 2009 (5). We prefer households' final consumption instead of the total final consumption because the total final consumption has a larger area (this includes, besides the households' final consumption $\mathrm{FCH}$, the final consumption of public and private administrations: non-profit institutions may be considered private administrations). As the VAT base consists of the households' final consumption and the intermediate consumption of administrations (not their final consumption), we prefer to restrain the potential VAT base area instead of enlarging it. 
The households' final consumption coefficient is found significant for a $1 \%$ risk threshold. The value of the households' final consumption coefficient is the biggest among all the considered potential tax bases, suggesting that households' final consumption has the greater impact upon VAT revenues. A one billion euro increase of the households' final consumption would determine an increase by EUR 0.11235 billion of the value-added type taxes revenues. This result confirms our intuition drawn from Figure 1, showing the higher impact of FCH on VAT receipts than GDP has. Sarmento (2016), in turn, explains the direct GDP-VAT revenues connection by the marginal propensity for consumption, particularly for goods and services subject to the normal rate.

The 2009 crisis induced certain peculiarities, which negatively influenced the VAT revenues of the EU-28 countries. Germany, Luxemburg and Austria were the only countries in which the VAT revenues did decrease in 2009. The coefficient of the dummy variable for 2009 is significant in three regressions from five. The 2009 idiosyncrasies have generally produced VAT revenues decreases resulting from the delayed tax payments, the taxevasion practices, or some isolated cases of VAT rates reduction.

Table 6

VAT revenues explained by the potential tax base

\begin{tabular}{|c|c|c|c|c|c|}
\hline $\begin{array}{c}\text { Dependent } \\
\text { variable } \\
\text { VAT revenues }\end{array}$ & (1) & (2) & (3) & (4) & (5) \\
\hline Constant & $\begin{array}{c}1247.61 * * * \\
(0.00)\end{array}$ & $\begin{array}{c}1361.43 \\
(0.31)\end{array}$ & $\begin{array}{c}1405.04 * * * \\
(0.00)\end{array}$ & $\begin{array}{c}1538.94 * * * \\
(0.00)\end{array}$ & $\begin{array}{c}2313.1^{* * *} \\
(0.00)\end{array}$ \\
\hline GDP & $\begin{array}{c}0.06484 * * * \\
(0.00)\end{array}$ & & & & \\
\hline $\begin{array}{l}\text { AGDP } \\
(\text { GDP + I - E) }\end{array}$ & & $\begin{array}{c}0.065587^{* * * *} \\
(0.00)\end{array}$ & & & \\
\hline GVA & & & $\begin{array}{c}0.071959 * * * \\
(0.00)\end{array}$ & & \\
\hline $\begin{array}{l}\text { GVAA } \\
(\text { GVA + I - E) }\end{array}$ & & & & $\begin{array}{c}0.07286^{* * *} \\
(0.00)\end{array}$ & \\
\hline FCH & & & & & $\begin{array}{c}0.11235^{* * * *} \\
(0.00)\end{array}$ \\
\hline Dummy_2009 & $\begin{array}{c}-1641.84^{*} \\
(0.0787) \\
\end{array}$ & $\begin{array}{c}-1801.07 \\
(0.11) \\
\end{array}$ & $\begin{array}{c}-1807.95 * \\
(0.0653) \\
\end{array}$ & $\begin{array}{c}-1987.01^{*} \\
(0.0964)\end{array}$ & $\begin{array}{r}-1833.07 \\
(0.2316) \\
\end{array}$ \\
\hline No. of observations & 474 & 474 & 474 & 474 & 474 \\
\hline
\end{tabular}

Notes: (1) The brackets stand for the risk threshold. (2) ***1\% significant coefficients, $* * 5 \%$ significant and $* 10 \%$ significant. The total number of observations is 476 (i.e. 28 countries observed over 17 years).

Source: authors' elaboration using the Gretl program. 
Table 6a

VAT revenues explained by the potential tax base in 2000-2009, the EU-28

\begin{tabular}{|c|c|c|c|c|c|}
\hline $\begin{array}{l}\text { Dependent variable } \\
\text { VAT revenues }\end{array}$ & (1) & (2) & (3) & (4) & (5) \\
\hline Constant & $\begin{array}{c}1338.76^{* * *} \\
(0.00)\end{array}$ & $\begin{array}{c}1382.54^{* * *} \\
(0.00)\end{array}$ & $\begin{array}{c}1498.7 * * * \\
(0.00)\end{array}$ & $\begin{array}{c}1555.08^{* * *} \\
(0.00)\end{array}$ & $\begin{array}{c}2380.06 * * * \\
(0.00)\end{array}$ \\
\hline GDP & $\begin{array}{c}0.06268^{* * *} \\
(0.00)\end{array}$ & & & & \\
\hline $\begin{array}{l}\text { GDPA } \\
(\text { GDP + I - E) }\end{array}$ & & $\begin{array}{c}0.06306^{* * *} \\
(0.00)\end{array}$ & & & \\
\hline GVA & & & $\begin{array}{c}0.069422^{* * *} \\
(0.00)\end{array}$ & & \\
\hline $\begin{array}{l}\text { GVAA } \\
(\text { GVA + I - E) }\end{array}$ & & & & $\begin{array}{c}0.069868^{* * * *} \\
(0.00)\end{array}$ & \\
\hline $\mathrm{FCH}$ & & & & & $\begin{array}{c}0.107433 * * * \\
(0.00)\end{array}$ \\
\hline No. of observations & 278 & 278 & 278 & 278 & 278 \\
\hline
\end{tabular}

Notes: (1) The brackets stand for the risk threshold. (2) ***1\% significant coefficients, $* * 5 \%$ significant and $* 10 \%$ significant. The total number of observations is 278 (i.e. 28 countries observed over 10 years).

Source: authors' elaboration using the Gretl program.

Table $6 \mathrm{~b}$

VAT revenues by the potential tax base in 2010-2016, the EU-28

\begin{tabular}{|c|c|c|c|c|c|}
\hline $\begin{array}{l}\text { Dependent variable } \\
\text { VAT revenues }\end{array}$ & (1) & (2) & (3) & (4) & (5) \\
\hline Constant & $\begin{array}{c}1109.29 * * * \\
(0.00)\end{array}$ & $\begin{array}{c}1331.34 * * * \\
(0.00)\end{array}$ & $\begin{array}{c}1243.88 * * * \\
(0.00)\end{array}$ & $\begin{array}{c}1494.62^{* * *} \\
(0.00)\end{array}$ & $\begin{array}{c}2200.95 * * * \\
(0.00)\end{array}$ \\
\hline GDP & $\begin{array}{c}0.066925^{* * *} \\
(0.00)\end{array}$ & & & & \\
\hline $\begin{array}{l}\text { GDPA } \\
(\text { GDP + I - E) }\end{array}$ & & $\begin{array}{c}0.068076^{* * *} \\
(0.00)\end{array}$ & & & \\
\hline GVA & & & $\begin{array}{c}0.0744339 \text { *** } \\
(0.00)\end{array}$ & & \\
\hline $\begin{array}{l}\text { GVAA } \\
(\text { GVA + I - E) }\end{array}$ & & & & $\begin{array}{c}0.075858 * * * \\
(0.00)\end{array}$ & \\
\hline FCH & & & & & $\begin{array}{c}0.11733^{* * * *} \\
(0.00)\end{array}$ \\
\hline No. of observations & 196 & 196 & 196 & 196 & 196 \\
\hline
\end{tabular}

Notes: (1) The brackets stand for the risk threshold. (2) ***means $1 \%$ significant coefficients, $* * 5 \%$ significant and $* 10 \%$ significant. The total number of observations is 196 (i.e. 28 countries observed over 7 years).

Source: authors' elaboration using the Gretl program. 
Our findings confirming that VAT revenue is highly correlated with the development of tax base, are in line with those presented in such studies as Legeida and Sologoub (2003), Slobodnitsky and Drucker (2008), and Sarmento (2016). The results validate hypothesis H1. The results under the fixed effects and random effects methodologies do not differ significantly.

Supplementary robustness checks were made by dividing the analysed period in the pre-crisis period (2000-2009) and the post-crisis period (2010-2016). The results are presented in Tables $6 \mathrm{a}$ and $6 \mathrm{~b}$, confirming the general finding that the more the tax base proxy is addressed, the bigger its impact is on VAT receipts. The households' final consumption has the greatest impact among tax base variables both in the pre-crisis and postcrisis periods. Although there is a small difference between FCH's effect before and after the crisis, a bigger coefficient for the second period would suggest that the connection has tightened recently. As we have seen, in the post-crisis period, the $\mathrm{FCH}$ and VAT growth rates diminish but they are more strongly related.

In a second stage of our research, we regress VAT revenues on the standard VAT rate and on the final consumption of households. Same sampled data and observation periods are analysed and the same methodology of panel econometrics is used. When the VAT rate changes during one year, we consider the prevailing rate for that year, e.g. the rate maintained for the great majority of the months in that year.

As the endogenous variable is expressed in millions of euros while the standard rate is expressed in percentages, we use the logarithmic form of both VAT revenues and FCH in order to re-scale, this being a common practice in econometric modelling. The results are presented in Table 7.

The regression 3 (Table 7) confirms that both the standard tax rate and households' final consumption are significant explicative variables of VAT revenues, showing a positive influence. Both $\mathrm{H} 1$ and $\mathrm{H} 2$ are corroborated. The consumption effect $(0.95)$ is more substantial than the tax rate effect (0.04), this result being similar to that obtained by Bogetic and Hassan (1993) or resulting from Sarmento's (2016) work. The negative and significant coefficient of the 2009 dummy variable points to the fact that in the crisis years there were particular factors that reduced VAT revenues, like fraud and errors in VAT management.

The two hypotheses are tested separately for the two sub-periods, before and after the crises (Tables $7 \mathrm{a}$ and $7 \mathrm{~b}$ ). The results obtained for the whole 
period are robust, i.e. the association between VAT receipts and VAT rate is strong and even more resilient by controlling for $\mathrm{FCH}$. Comparing the results on the two sub-periods, we may assert that VAT rate changes had more profound effects on the VAT receipts in the pre-crisis and crisis

Table 7

Log VAT revenues explained by the standard rate and the log final consumption of households

\begin{tabular}{l|c|c|c}
\hline $\begin{array}{c}\text { Dependent variable } \\
\text { (Log VAT) }\end{array}$ & $\mathbf{( 1 )}$ & $\mathbf{( 2 )}$ & $\mathbf{( 3 )}$ \\
\hline Constant & $\begin{array}{c}6.64213^{* * *} \\
(0.00)\end{array}$ & $\begin{array}{c}-1.57761^{* * *} \\
(0.00)\end{array}$ & $\begin{array}{c}-2.28027^{* * *} \\
(0.00)\end{array}$ \\
\hline RATE & $0.128085^{* * *}$ & & $0.04086^{* * *}$ \\
& $(0.00)$ & & $(0.00)$ \\
\hline Log FCH & & $0.96332^{* * *}$ & $0.95244^{* * *}$ \\
& & $(0.00)$ & $(0.00)$ \\
\hline Dummy_2009 & & & $-0.03195^{*}$ \\
& & 474 & $(0.0572)$ \\
\hline No of observations & 47474 \\
\hline
\end{tabular}

Notes: (1) The brackets stand for the risk threshold. (2) $* * * 1 \%$ significant coefficients, $* * 5 \%$ significant and $* 10 \%$ significant. The total number of observations is 474 (i.e. 28 countries observed over 17 years).

Source: authors' elaboration using the Gretl program.

Table $7 \mathrm{a}$

Log VAT revenues explained by the standard rate and the log final consumption of households, 2000-2009

\begin{tabular}{l|c|c|c}
\hline $\begin{array}{c}\text { Dependent variable } \\
\text { (Log VAT) }\end{array}$ & $\mathbf{( 1 )}$ & $\mathbf{( 2 )}$ & $\mathbf{( 3 )}$ \\
\hline Constant & $6.51383^{* * *}$ & $-1.68401^{* * *}$ & $-2.50527^{* * *}$ \\
& $(0.00)$ & $(0.00)$ & $(0.00)$ \\
\hline RATE & $0.131761^{* * *}$ & & $0.048656^{* * *}$ \\
& $(0.00)$ & & $(0.00)$ \\
\hline Log FCH & & $0.970181^{* * *}$ & $0.958545^{* * *}$ \\
& & $(0.00)$ & $(0.00)$ \\
\hline No of observations & 278 & 278 & 278 \\
\hline
\end{tabular}

Note: (1) The brackets stand for the risk threshold. (2) *** $1 \%$ significant coefficients, ** $5 \%$ significant and * $10 \%$ significant. The total number of observations is 278 (i.e. 28 countries observed over 10 years).

Source: authors' elaboration using the Gretl program. 
Table $7 \mathrm{~b}$

Log VAT revenues explained by the standard rate and the log final consumption of households, 2010-2016

\begin{tabular}{l|c|c|c}
\hline $\begin{array}{c}\text { Dependent variable } \\
\text { (Log VAT) }\end{array}$ & (1) & (2) & (3) \\
\hline Constant & $\begin{array}{c}7.30143^{* * *} \\
(0.00)\end{array}$ & $\begin{array}{c}-1.35247^{* * *} \\
(0.00)\end{array}$ & $\begin{array}{c}-1.85280^{* * *} \\
(0.00)\end{array}$ \\
\hline RATE & $\begin{array}{c}0.100777^{* *} \\
(0.017)\end{array}$ & & $\begin{array}{c}0.02648^{* * *} \\
(0.00)\end{array}$ \\
\hline Log FCH & & $0.947336^{* * *}$ & $\begin{array}{c}0.94194^{* * *} \\
(0.00)\end{array}$ \\
\hline No of observations & 196 & $1960)$ & 196 \\
\hline
\end{tabular}

Note: (1) The brackets stand for the risk threshold. (2) ***1\% significant coefficients, $* * 5 \%$ significant and $* 10 \%$ significant. The total number of observations is 196 (i.e. 28 countries observed over 7 years).

Source: authors' elaboration using the Gretl program.

periods than in the subsequent years. The FCH impact on VAT revenues does not vary significantly from one period to another. FCH remains the most important determinant for VAT receipts.

Regressing VAT revenues on the standard tax rate and, then, regressing VAT revenues on the final consumption of households has an important practical utility. By distinguishing the way the VAT revenues adjust to the changes in consumption (e.g. a decreasing trend of consumption), we may further estimate what VAT rate amendments are needed in order to cover the VAT revenues losses caused by diminishing $\mathrm{FCH}$.

As the results of regression 1 shows (Table 7), there is a strong and direct correlation between the VAT rate and the VAT revenues in the EU countries. A one percentage point increase of the standard VAT rate multiplies VAT receipts by 1.12 , although it rises by $12 \%$. The results of regression 2 (Table 7) confirm the previous finding of the strong relationship between consumption and VAT revenues. Logarithmic transformation of the variables allows noticing the elasticity of VAT revenues towards the VAT base. An elasticity of about 0.96 corresponds to what is specific to developed countries, suggesting that VAT revenue is elastic to the VAT base (Legeida and Sologoub, 2003). 
Considering the following two relations derived from regressions (1) and (2), Table 7:

$$
\operatorname{Ln} \mathrm{VAT}=0.96 \times \mathrm{Ln} \mathrm{FCH}-1.57
$$

and

$$
\mathrm{Ln} \mathrm{VAT}=0.12 \times \mathrm{RATE}+6.64
$$

we may state that a $1 \%$ decrease of consumption has further led to an average decrease of $0.99 \%$ in the VAT revenues of the EU-28 countries in the analysed period. A $1 \%$ FCH decrease led to a decrease in Ln VAT by $0.96 \times \operatorname{Ln} 0.99$, i.e. a decrease in Ln VAT by 0.0096 , which is equivalent to $\operatorname{Ln} \mathrm{VAT}-0.0096=\operatorname{Ln}\left(\mathrm{VAT} / \mathrm{e}^{0.0096}\right)$. In order to find the amount A of the VAT revenues decrease, we proceed in the following way: $\mathrm{VAT} / \mathrm{e}^{0.0096}=\mathrm{VAT}-\mathrm{A}$, resulting in: $\mathrm{A}=\mathrm{VAT} \times\left(1-1 / \mathrm{e}^{0.0096}\right)=\mathrm{VAT} \times 0.0099$, so VAT diminishes by $0.99 \%$. The tax rate should have to increase by 0.08 percentage points on average in order to offset that loss. Increasing VAT receipts by $0.99 \%$ means to increase Ln VAT by 0.0096 , which assumes the equivalence:

$0.12 \times \mathrm{RATE}+0.0096=0.12(\mathrm{RATE}+0.0096 / 0.12)=0.12(\mathrm{RATE}+0.08)$, so the RATE should rise by $0.08 \mathrm{pp}$. Based on this finding, we may establish the theoretical VAT rate change in connection with effective $\mathrm{FCH}$ variations. Data in Table 5 are used in order to find out which theoretical VAT rate changes would allow balancing the VAT receipts variations induced by FCH adjustments. There are 56 cases of VAT rates reassessments, and for each of them we compare the effective VAT rate adjustments with the theoretical ones (Figure 2).

For only one-fifth of the cases of VAT rate variations, the government decision almost matches the theoretical model. There were a lot of situations for which, even though theoretically the tax rate should have slightly increased or even decreased (as a result of an increase in consumption), actually it significantly rose. Out of the 46 cases of VAT rate increases, in only 19 situations the VAT rate should have increased and for the rest of them the VAT rate should have decreased, according to our theoretical predictions. Government measures of VAT rate increases that lack economic reasoning lead to a higher fiscal burden on tax payers. 


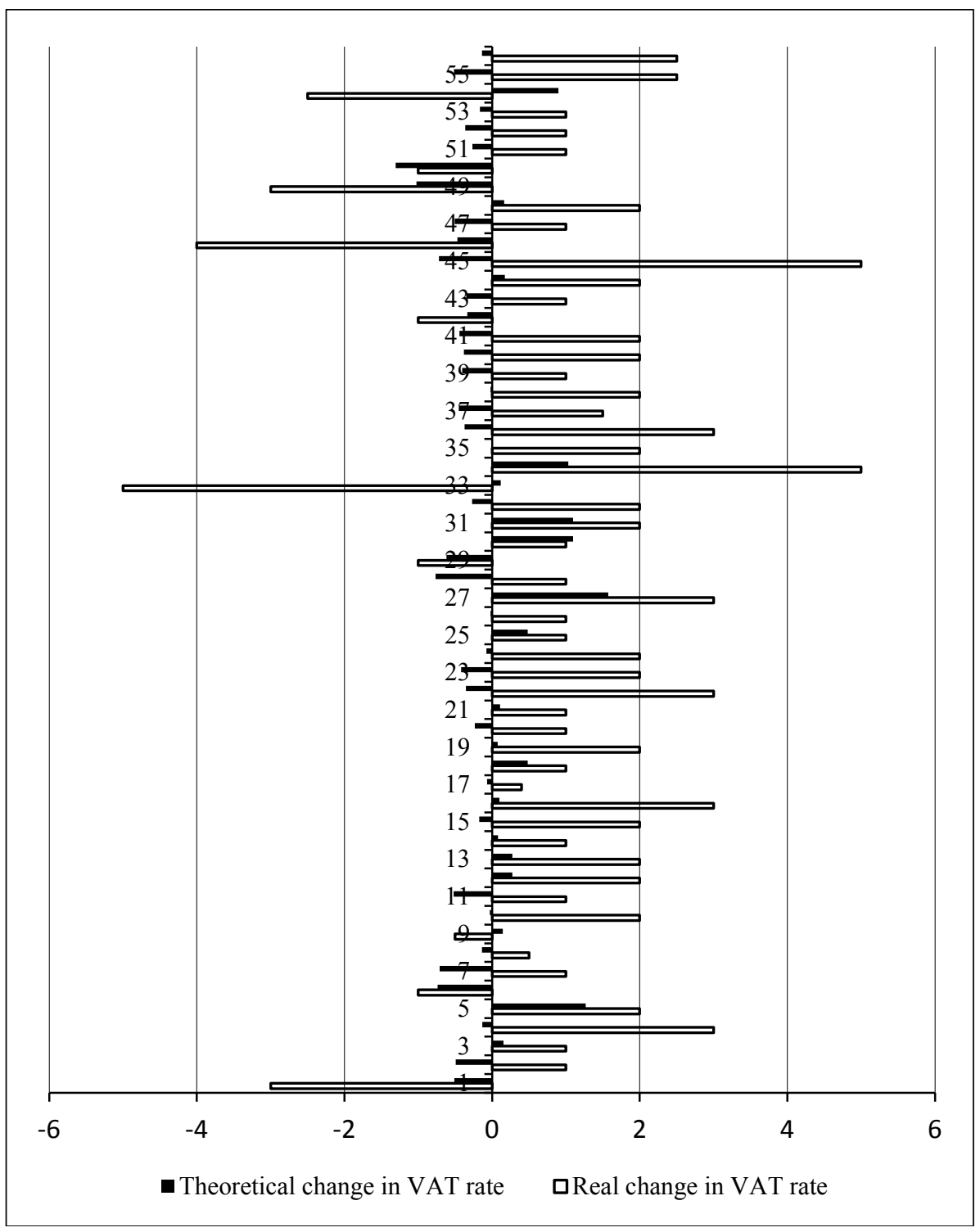

Fig. 2. VAT rate reassessments, the effective situation and the theoretical predicted situation

Note: There are 56 situations of tax rate changes. The data represent effective reassessments of the VAT rate (percentage points) and theoretical modifications of the VAT rate (resulting from the relationship we established between the final consumption and the VAT rate).

Source: authors' elaboration using Eurostat data. 


\section{CONCLUSIONS AND POLICY IMPLICATIONS}

This study fills the gap in VAT-dedicated literature by discussing the main determinants of VAT revenues. The contributions are scarce in this field, especially when referring to the EU countries. We believe that studying the basic factors that impact VAT revenues is an important issue, especially from the public policy perspective, as it suggests what measures are to be taken in order to increase tax revenues. This is particularly crucial when the economy faces a crisis.

VAT revenues generally represent an important and stable share in the EU-28 Member States budgets. The less developed EU countries are the most VAT-dependent. In the long run, an increasing share of VAT revenues can be observed in the EU-28. Moreover, developing a reliance on VAT receipts in times of crisis was the best solution seen by governments facing economic growth concerns. Extending the VAT tax base, reassessing the VAT rates and ensuring a better tax management are the three main ways envisaged for preserving or even increasing the share of VAT revenues in the state budget.

The steps taken by the European Commission focused on making the VAT system simpler, more robust, efficient, and effective against VAT fraud, were all welcome in the after-crisis period due to their VAT-base growth effect. However, it seems that these measures were not entirely effective as a new VAT fraud-reducing approach was developed recently by conceiving a single EU VAT area. Apart from the EU initiatives in the VAT area, each member state deals with VAT reliance issues in its own way, usually by reassessing the VAT rate system. In the analysed period, and particularly after 2008, the most common strategies consisted in raising the standard rate and restricting special treatments, as a large number of the EU countries faced fiscal deficit constraints. Almost 60 attempts to reassess the VAT standard rate occurred in more than half of the EU countries, this being more frequent after 2010.

Our contribution suggests more profound variations for VAT revenues than FCH observed deviations, i.e. VAT revenues decreased in 2009 and increased in 2010 at a higher rate than FCH in half of the analysed countries, and it increases faster than $\mathrm{FCH}$ in almost 80 percent of the EU-28 during the after-crisis period. While nominal VAT revenues follow a cycle in times of crisis, VAT receipts share increased continuously from 2007 to 2012, suggesting that other government incomes faced more serious damages during the crisis (i.e. revenues and company profits as tax bases were 
seriously hit, and eventually the associated tax burden was maintained or even reduced).

Besides allowing to infer the $\mathrm{FCH}$ impact on VAT revenues, our descriptive analysis calls for an interrelation between VAT rate revisions and the consumption path. Increasing VAT rates generally results in decreased consumption in the short run and FCH growth rate recovery in the long run. A similar outcome is produced by VAT rate rises on VAT receipts that, at best, reduce its growth rate. A stronger connection between VAT revenues and the FCH path than with the VAT rate is predicted by our descriptive analysis.

Empirical analysis asserts that final consumption of households is the best approximation for the VAT base, among other macroeconomic variables available for research. The final consumption of households has the greatest impact on VAT revenues among tax base variables both in pre-crisis and post-crisis periods. Moreover, the connection is likely to tighten in the post-crisis period. By regressing VAT receipts on both the standard VAT rate and $\mathrm{FCH}$, we found that the consumption effect is more substantial than the VAT rate effect. The VAT rate reassessments impact on VAT revenues is stronger during the pre-crisis and crisis periods than in the subsequent years. FCH remain the most important determinant for VAT receipts.

As we have witnessed many VAT rates reassessments occurring in the last decade in the EU-28, we wonder how many of them were correctly grounded. Our regressions' results allow to establish the theoretical VAT rate changes that would allow balancing the VAT receipts variations induced by FCH adjustments. By comparing the effective VAT rate adjustments with the theoretical ones, we conclude that for only one-fifth of the VAT rate variations cases, the government decisions match the theoretical model, while for the rest of them unjustified increases are recorded.

All in all, focusing particularly on the standard VAT rate and various proxies for the VAT base, as determinants of VAT revenues, our analysis highlights the limits of a public budget relying on VAT revenues. These limitations mainly arise from the fact that VAT revenues are dependent on the overall economic development and final consumption. Our descriptive and empirical analysis supports the hypothesis according to which household final consumption is a more relevant determinant of VAT revenues, than the VAT standard rate. In other words, reassessing the VAT rate system is a less effective way to increase VAT revenues than enlarging the VAT base. It is economic development, and especially private consumption, that actually determine the trend of VAT revenues. 
Some implications in terms of public policy are emerging. When the economy faces a crisis, the final consumption of households has to be encouraged in order to avoid a serious fall of the so desperately needed public money in those times. This has to be a matter of priority, instead of immediately increasing the VAT rate. Various forms of consumption stimulation and side effects do not constitute the subject of the present study. However, we are only saying this should be done prudently. Developing the VAT base is also possible by finding the best means for reducing VAT fraud and the VAT gap and for enlarging the tax base subject to a standard rate. Some actions in this field have already been put into practice by the EU-28 countries and need to continue.

On the other hand, our analysis calls for a well-grounded government VAT rate reassessment, in connection with the economic trend (i.e. a private consumption path). In this way an unreasonable increase of the fiscal burden can be avoided. However, in this approach some other factors influencing VAT revenues should also be considered, as these factors impact especially in times of crisis (e.g. difficulties in budget execution).

\section{REFERENCES}

Ángeles Castro, G., Ramírez Camarillo, D. B., Determinants of tax revenue in OECD countries over the period 2001-2011, "Contaduría y Administración", 59 (3), pp. 35-59, 2014.

Bogetic, Z., Hassan, F., Determinants of Value Added-Tax Revenue: A Cross-Section Analysis, Policy Research Working Papers, The World Bank, 1993.

Collins, M., The Distributive Effects of Recent VAT Changes in the Republic of Ireland, NERI WP no. 19, 2014.

COM 807, On a coordinated strategy to improve the fight against VAT fraud in the European Union, Communication from the Commission to the Council, the European Parliament, the European Economic and Social Committee, Commission of the European Communities, Brussels, 1.12.2008.

COM 851, Towards a simpler, more robust and efficient VAT system tailored to the single market, Communication from the Commission to the European Parliament, the Council and the European Economic and Social Committee on the future of VAT, European Commission, Brussels, 6.12.2011.

COM 148 final, Towards a single EU VAT area - Time to decide, Communication from the Commission to the European Parliament, the Council and the European Economic and Social Committee on an action plan on VAT, European Commission, Brussels, 7.4.2016.

COM 566 final, Towards a single EU VAT area - Time to act, Communication from the Commission to the European Parliament, the Council and the European Economic and Social Committee on the follow-up to the Action Plan on VAT, European Commission, Brussels, 4.10.2017.

Cornelisse, R., Hulsebos, K., US VAT Introduction: Any Lessons to Be Learned from European VAT Fraud? [in;] Indirect Tax Strategic Plan, US VAT introduction on 07/03, 2012. 
Council Regulation (EU) 904, On administrative cooperation and combating fraud in the field of value added tax, "Official Journal of the European Union", L 268, October 2010.

Ebeke, C., Ehrhart, H., Does VAT reduce the instability of tax revenues?, CERDI, Etudes et Documents, E 2011.24, 2011.

Gastaldi, F., Liberati, P., Pisano, E., Tedeschi, S., Regressivity-Reducing VAT Reforms, "International Journal of Microsimulation”, 10(1), pp. 39-72, 2017.

IMF, From stimulus to consolidation : revenue and expenditure policies in advanced and emerging economies, a staff team led by Benedict Clements, Victoria Perry, and Juan Toro. International Monetary Fund, Washington, D.C., 2010.

Jenkins, G. P., Kuo, C. Y., A VAT Revenue Simulation Model for Tax Reform in Developing Countries. Harvard Institute for International Development, 1995.

Jenkins, G., Kuo, C., Shukla, G., Tax Analysis and Revenue Forecasting - Issues and Techniques. Harvard Institute for International Development, Harvard University, 2000.

Keen, M., VAT attacks!, "Int. Tax Public Finance” 14, pp. 365-381, 2007.

Keen, M., Smith, S., VAT Fraud and Evasion: What Do We Know, and What Can be Done?, Fiscal Affairs Department, IMF Working Paper 07/31, 2007.

Keen, M., Lockwood, B., The value added tax: its causes and consequences, "Journal of Development Economics" 92, pp. 138-151, 2010.

Legeida, N., Sologoub, D., Modelling Value Added Tax Revenues in a Transition Economy: Case of Ukraine, Institute for Economic Research and Policy Consulting, Working Paper no. 2, 2003.

Martinez-Vazquez, J., Bird, R. M., Value Added Tax: Onward and Upward?, International Studies Program, Andrew Young School of Policy Studies, Georgia State University, Working Paper 10-26, 2010.

Olexa, M., Analysis and Econometric Modelling of the Fiscal Sector in the Slovak Republic, Institute for Advanced Studies, Vienna, Transition Economics Series no. 2, 1999.

Owens, J., Battiau, P., Charlet, A., VAT's next half century: Towards a single rate system?, The OECD Observer, no. 284, F1, pp. 20-22, 2011.

Radu, C. F., Tax burden and the economic crisis, "The Scientific Journal of Humanistic Studies", no. 6, 2012.

Sarmento, J., The Determinants of Value Added Tax Revenues in the European Union, "The European Journal of Management Studies”, vol. 21, issue 2, pp.79-99, 2016.

Slobodnitsky, T., Drucker, L., VAT Revenue Forecasting in Israel, Ministry of Finance, State Revenue Administration, Falk Institute's "Policy Teams" project, 2008.

TAXUD, A Study on the Economic Effects of the Current VAT rates structure, European Commission, 2013.

TAXUD, Study and Reports on the VAT Gap in the EU-28 Member States, European Commission, 2017.

Tulai, C., Serbu, S., Comparative Taxation and Fiscal Harmonization, Casa Cărții de Știință. Cluj-Napoca, 2005

Wawire, N., Determinants of Value Added Tax Revenue in Kenya, CSAE conference paper, March 2011.

Received: August 2014, revised: September 2018 